\title{
Efficacy and Safety of the Woven EndoBridge (WEB) Device for the Treatment of Intracranial Aneurysms: A Systematic Review and Meta-Analysis
}

\author{
(D) S. Asnafi, (D) A. Rouchaud, (DL. Pierot, (D) W. Brinjikji, (D) M.H. Murad, and DD.F. Kallmes
}

\begin{abstract}
BACKGROUND AND PURPOSE: Intrasaccular flow diverters are increasingly being used in the treatment of wide-neck and bifurcation aneurysms. We performed a systematic review and meta-analysis of existing literature on the Woven EndoBridge device in the treatment of intracranial aneurysms.

MATERIALS AND METHODS: A comprehensive literature search was performed through October 1, 2015. We extracted information on baseline aneurysm and patient characteristics. Outcomes studied included immediate and midterm ( $>3$ month) angiographic outcomes (complete occlusion as well as adequate occlusion, defined as complete occlusion or neck remnant), aneurysm retreatment, intraoperative rupture, perioperative morbidity and mortality, thromboembolic complications, and treatment failure. Meta-analysis was performed by using the random-effects model.
\end{abstract}

RESULTS: Fifteen uncontrolled series were included in this analysis, including 565 patients with 588 aneurysms, of which 127 were ruptured. Initial complete and adequate occlusion rates were $27 \%(95 \% \mathrm{Cl}, 15 \%-39 \%)$ and $59 \%(95 \% \mathrm{Cl}, 39 \%-78 \%)$, respectively. Midterm complete and adequate occlusion rates after a median of 7 months were $39 \%(95 \% \mathrm{Cl}, 26 \%-52 \%)$ and $85 \%(95 \% \mathrm{Cl}, 78 \%-91 \%)$, respectively. Perioperative morbidity and mortality rates were $4 \%(95 \% \mathrm{Cl}, 1 \%-8 \%)$ and $1 \%(95 \% \mathrm{Cl}, 0 \%-2 \%)$, respectively. Midterm adequate occlusion rates for ruptured aneurysms were $85 \%(95 \% \mathrm{Cl}, 67 \%-98 \%)$, compared with $84 \%(95 \% \mathrm{Cl}, 72 \%-94 \%)$ for unruptured aneurysms $(P=.89)$. Patients with ruptured aneurysm had similar rates of perioperative morbidity to patients with unruptured aneurysm $(2 \% ; 95 \% \mathrm{Cl}, 0 \%-26 \%$ versus $2 \% ; 95 \% \mathrm{Cl}, 0 \%-6 \%$, respectively; $P=.35)$.

CONCLUSIONS: Early evidence derived from uncontrolled studies suggests that Woven EndoBridge treatment has a good safety profile and promising rates of adequate occlusion, especially given the complexity of aneurysms treated. Further prospective clinical trials are needed to confirm these results and better define the risks and benefits of use of the Woven EndoBridge device in treating wide-neck and wide-neck bifurcation aneurysms.

ABBREVIATION: WEB $=$ Woven EndoBridge

W

ith the advent of stent-assisted and balloon-assisted coiling, wide-neck and wide-neck bifurcation intracranial aneurysms are increasingly treated with endovascular techniques. Both stent-assisted and balloon-assisted coiling have been shown safe and effective in treating these aneurysms by allowing for increased packing and lower rates of parent artery occlusion com-

Received April 4, 2016; accepted after revision June 24

From the Department of Radiology (S.A., A.R., W.B., D.F.K.) and Center for the Science of Healthcare Delivery (M.H.M.), Mayo Clinic, Rochester, Minnesota; and Department of Neuroradiology (L.P.), Maison Blanche Hospital, University of Reims Champagne-Ardenne, Reims, France.

Please address correspondence to Waleed Brinjikji, MD, Department of Radiology, Mayo Clinic, 200 First St SW, Rochester, MN 55905; e-mail: brinjikji.waleed@mayo.edu; @wbrinjikji

三 Indicates article with supplemental on-line table.

http://dx.doi.org/10.3174/ajnr.A4900 pared with conventional coiling alone. ${ }^{1-7}$ However, because of less than satisfactory occlusion rates with coil embolization of wide-neck and wide-neck bifurcation aneurysms, there has been a push toward treating these lesions with intrasaccular and intraluminal flow diverters.

The Woven EndoBridge (WEB; Sequent Medical, Aliso Viejo, California) is a nitinol braided-wire intravascular device designed to disrupt blood flow at the aneurysmal neck. This device is specifically designed for the treatment of wide-neck bifurcation aneurysms. ${ }^{8,9}$ To date, several case series have demonstrated that the WEB device is both safe and effective in treatment of wide-neck and wide-neck bifurcation aneurysms. ${ }^{10-13}$ We present the results of a systematic review and meta-analysis examining outcomes of endovascular treatment of wide-neck and wide-neck bifurcation aneurysms with the WEB device. The aim of our study was to assess both angiographic and clinical outcomes. 


\section{MATERIALS AND METHODS \\ Literature Search}

A comprehensive literature search of 3 data bases (PubMed, Ovid MEDLINE, and Ovid EMBASE) was designed and conducted by an experienced librarian with input from the authors. The keywords "intracranial aneurysm," "cerebral aneurysm," "aneurysm," "wide-neck," "bifurcation," "WEB device," and "intraluminal flow diverter" were used in both "AND" and "OR" combinations. The search was limited to articles published from January 1, 2010, to October 1, 2015, and was supplemented by contacting experts in the field for any additional studies. All studies reporting patients with aneurysms treated with the WEB device were included. Inclusion criteria were the following: 1) English language, 2) study reporting a consecutive series of aneurysms treated with the WEB device, and 3) series of at least 5 patients reporting angiographic and/or clinical outcomes. Review articles, comments, guidelines, technical notes, and editorials were excluded. Two of the authors selected the included studies. A third author arbitrated in cases of disagreement.

\section{Outcomes and Data Extraction}

For each study, we extracted the following baseline information: number of patients, aneurysm rupture status, patient sex, mean age, use of core lab in assessing angiographic outcomes, number of aneurysms treated, mean aneurysm size, mean aneurysm neck size, length of clinical follow-up, and length of angiographic follow-up.

Outcomes studied included immediate and midterm $(>3$ month) angiographic outcomes (complete occlusion and adequate occlusion, which was defined as complete occlusion or neck remnant), aneurysm retreatment, intraoperative rupture, perioperative morbidity and mortality, thromboembolic complication, and treatment failure. Treatment failure was defined as a failed attempt at WEB device placement. Outcomes were calculated for the overall patient population with subgroup analysis by rupture status (ruptured versus unruptured). Morbidity was defined as $\mathrm{mRS}$ score $>1$. There were variable classification scales to assess aneurysm occlusion used in this study. For studies that used the WEB Occlusion Scale, complete occlusion was defined as no contrast opacification of the aneurysm with or without contrast opacification of the proximal recess of the device. Earlier studies that did not use the WEB Occlusion Scale and used the Raymond scale instead often classified contrast opacification of the proximal recess of the device as a neck remnant or did not specify recess opacification rates. Thus, for the purposes of this meta-analysis, we report adequate occlusion, which was defined as complete occlusion or neck remnant (complete occlusion with opacification of the neck).

\section{Study Risk of Bias}

We modified the Newcastle-Ottawa Quality Assessment Scale for Case Control Studies to assess the risk of bias of the studies included in this meta-analysis. This tool is designed for use in comparative studies; however, because none of the included studies were controlled, we assessed study risk of bias based on selected items from the tool, focusing on the following questions: 1) did the study include all patients or consecutive patients versus a selected sample?; 2) was the study retrospective or prospective?; 3) was angio-

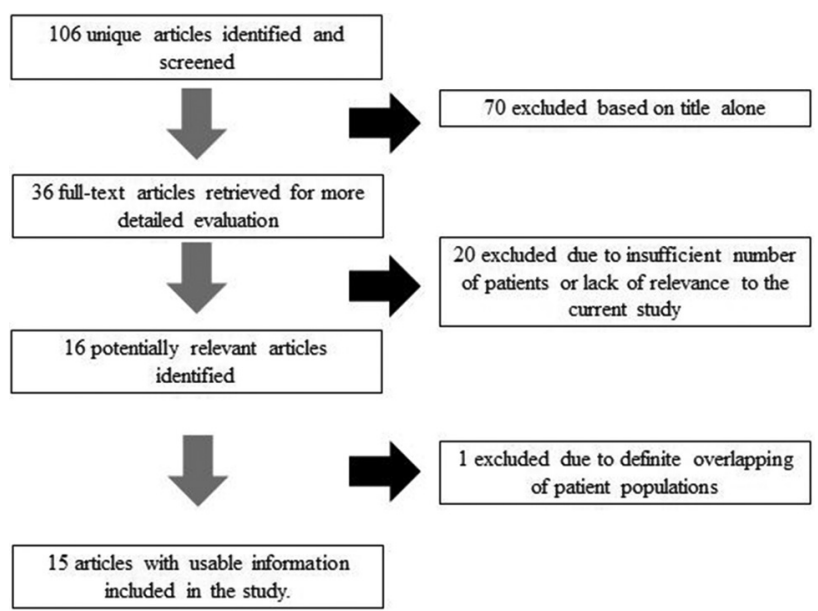

FIG 1. Search strategy results.

graphic and clinical follow-up satisfactory, thus allowing for ascertainment of all outcomes?; 4) were outcomes clearly reported?; and, 5) were the interventionalists treating the patients the same as those who assessed angiographic and clinical outcomes?

\section{Statistical Analysis}

We estimated from each study the cumulative incidence (event rate at the end of the study) and 95\% CI. Because we anticipated marked heterogeneity in the populations and interventions across the various included studies, a random-effects model was used to pool incidence rates across studies. ${ }^{14}$ Variance was estimated by using the Freeman-Tukey double arcsine method. ${ }^{15}$ The I ${ }^{2}$ statistic was used to express the proportion of inconsistency that is not attributable to chance. ${ }^{16}$ Analysis was conducted by using STATA Statistical Software: Release 14 (StataCorp, College Station, Texas).

\section{RESULTS}

\section{Study Selection and Characteristics}

The initial literature search yielded 106 articles. Upon review of the abstracts and titles, 90 articles were excluded. Sixteen articles were selected for full-text screening. In total, 15 studies including 565 patients with 588 aneurysms were included. Of these, 127 aneurysms (22\%) were ruptured and 461 aneurysms (78\%) were unruptured; in no case was the rupture status unknown. There were 470 aneurysms $(80 \%)$ in the anterior circulation and 118 $(20 \%)$ in the posterior circulation. Seventy-three aneurysms $(12.0 \%)$ were treated with adjunctive coiling, stent placement, or stent-assisted coiling. Type of pre- and postoperative antiplatelet therapy varied widely between studies.

Of the 15 studies, 6 had a low risk of bias, 3 had a high risk of bias, and 6 had a moderate risk of bias. The smallest study had 6 patients with 6 aneurysms, and the largest study had 90 patients with 98 aneurysms. Eleven studies had angiographic follow-up at 6 months or longer. A summary of included studies is provided in the On-line Table. Flow chart for study selection is provided in Fig 1.

\section{Overall Outcomes}

The WEB treatment outcomes are presented in Table 1. Initial complete occlusion rates and adequate occlusion rates were $27 \%$ (95\% CI, 15\%-39\%) and 59\% (95\% CI, 39\%-78\%), respectively. 
Midterm complete occlusion rates after a median of 7 months were $39 \%$ (95\% CI, 26\%-52\%) and midterm adequate occlusion rates were $85 \%$ (95\% CI, 78\%-91\%) (Fig 2). Treatment failure occurred in $3 \%$ of cases $(95 \%$ CI, $1 \%-6 \%)$. Perioperative morbidity and mortality rates were $4 \%(95 \% \mathrm{CI}, 1 \%-8 \%)$ and $1 \%$ (95\% CI, 0\%-2\%), respectively. The rate of thromboembolic complications was $8 \%(95 \%$ CI, 5\%-12\%). Midterm good neurologic outcome rates are provided in Fig 3.

\section{Angiographic and Clinical Outcomes by Rupture Status}

The rate of midterm complete occlusion was 45\% (95\% CI, 25\%$65 \%)$ for the ruptured group and $22 \%(11 \%-33 \%)$ for the unruptured group $(P=.008)$. The rate of midterm adequate occlusion for ruptured aneurysms was $85 \%$ (95\% CI, 67\%-98\%), compared

Table 1: Summary of outcomes

\begin{tabular}{lcc}
\hline \multicolumn{1}{c}{ Outcome } & $\begin{array}{c}\text { Event Rate (\%) } \\
(95 \% \mathrm{Cl})\end{array}$ & $\begin{array}{c}\text { Raw } \\
\text { Proportion }\end{array}$ \\
\hline Initial complete occlusion & $27(15-39)^{\mathrm{a}}$ & $76 / 277$ \\
Initial adequate occlusion & $59(39-78)^{\mathrm{a}}$ & $132 / 277$ \\
Midterm complete occlusion & $39(26-52)^{\mathrm{a}}$ & $168 / 362$ \\
Midterm adequate occlusion & $85(78-91)$ & $209 / 261$ \\
Midterm good neurologic & $96(94-98)$ & $328 / 346$ \\
$\quad$ outcome & & \\
Intraoperative rupture & $1(0-2)$ & $12 / 556$ \\
Perioperative morbidity & $4(1-8)^{\mathrm{a}}$ & $29 / 449$ \\
Perioperative mortality & $1(0-2)$ & $13 / 517$ \\
Thromboembolic complication & $8(5-12)$ & $56 / 556$ \\
Retreatment & $6(1-12)^{\mathrm{a}}$ & $37 / 501$ \\
Treatment failure & $3(1-6)$ & $27 / 543$ \\
\hline
\end{tabular}

${ }^{a}$ Indicates $I^{2}$ value above 50\% (substantial heterogeneity).

\begin{tabular}{|c|c|c|}
\hline $\begin{array}{l}\text { Author, } \\
\text { Year }\end{array}$ & $\begin{array}{l}\mathrm{N} \\
\text { event }\end{array}$ & $\begin{array}{l}\mathrm{N} \\
\text { Total }\end{array}$ \\
\hline Bozzetto Ambrosi 2015 & 7 & 8 \\
\hline Behme, 2015 & 29 & 44 \\
\hline Caroff, 2014 & 4 & 6 \\
\hline Cognard, 2015 & 9 & 14 \\
\hline Gherasim, 2015 & 6 & 7 \\
\hline Lescher, 2016 & 23 & 23 \\
\hline Lubicz, 2014 & 26 & 29 \\
\hline Liebig, 2015 & 20 & 25 \\
\hline Lubicz, 2013 & 17 & 19 \\
\hline Pierot, 2012 & 12 & 15 \\
\hline Pierot, 2013 & 25 & 30 \\
\hline Papagiannaki, 2014 & 60 & 65 \\
\hline Pierot. 2016 & 82 & 100 \\
\hline
\end{tabular}

with $84 \%$ (95\% CI, 72\%-94\%) for unruptured aneurysms ( $P=$ $.89)$. Data on initial occlusion by rupture status were not consistently reported, and no meta-analysis could be performed for this outcome.

Patients with ruptured aneurysms had similar rates of perioperative morbidity as those with unruptured aneurysms (2\%; $95 \%$ CI, $0 \%-26 \%$ versus 2\%; 95\% CI, $0 \%-6 \%$, respectively; $P=.35$ ). Rates of intraoperative rupture in ruptured and unruptured aneurysms were $6 \%(95 \% \mathrm{CI}, 0 \%-11 \%)$ and $1 \%(95 \% \mathrm{CI}, 0 \%-3 \%)$, respectively $(P=.08)$. Treatment failure occurred at a higher rate for unruptured aneurysms $(6 \%$; 95\% CI, 3\%-9\%) compared with the ruptured aneurysms $(0 \%$; 95\% CI, $0 \%-4 \%)(P=.04)$. These results are presented in Table 2.

\section{DISCUSSION}

This systematic review and meta-analysis of 15 uncontrolled studies demonstrated that treatment of wide-neck bifurcation aneurysms with the WEB device was achieved with high rates of technical success and low rates of complications. Initial adequate occlusion rate was nearly $60 \%$, and adequate occlusion rate at follow-up was $85 \%$. There were no substantial differences in outcomes by rupture status. These findings are important because they suggest that the WEB device might be a valuable tool in the treatment of wide-neck bifurcation aneurysms regardless of rupture status.

As demonstrated by this meta-analysis, a number of prior studies have examined the safety and efficacy of the WEB device. In a systematic review of 6 studies by Armoiry et al, ${ }^{17}$ the authors reported high rates of treatment feasibility $(93 \%-100 \%)$ with ad- 


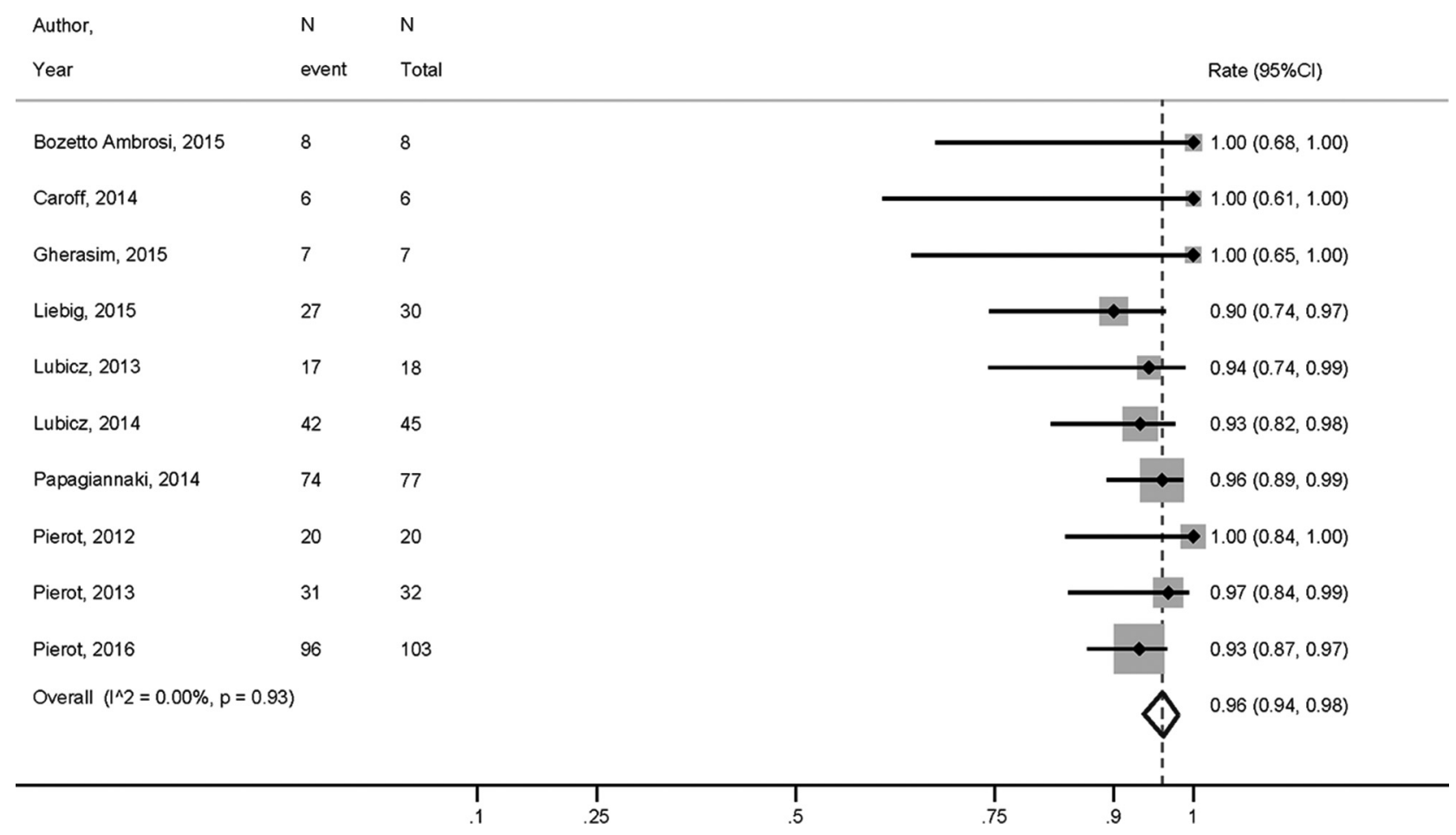

FIG 3. Midterm good neurologic outcome rates.

Table 2: Outcomes by rupture status

\begin{tabular}{|c|c|c|c|c|c|}
\hline Outcome & $\begin{array}{l}\text { Ruptured Group Event } \\
\text { Rate }(\%)(95 \% \mathrm{Cl})\end{array}$ & $\begin{array}{c}\text { Raw } \\
\text { Proportion }\end{array}$ & $\begin{array}{l}\text { Unruptured Group Event } \\
\text { Rate }(\%)(95 \% \mathrm{Cl})\end{array}$ & $\begin{array}{c}\text { Raw } \\
\text { Proportion }\end{array}$ & $P$ Value \\
\hline Initial adequate occlusion & $100(57-100)$ & $4 / 4$ & 70 (44-91) & $49 / 73$ & .24 \\
\hline Midterm complete occlusion & $45(25-65)$ & $18 / 35$ & $22(11-33)$ & $22 / 89$ & .008 \\
\hline Midterm adequate occlusion & 85 (67-98) & $33 / 44$ & $84(72-94)$ & $76 / 118$ & .89 \\
\hline Intraoperative rupture & $6(0-11)$ & $4 / 79$ & $1(0-3)$ & $3 / 220$ & .08 \\
\hline Perioperative morbidity & $2(0-26)^{a}$ & $14 / 70$ & $2(0-6)$ & $5 / 145$ & .35 \\
\hline Perioperative mortality & $15(7-23)$ & $11 / 69$ & $0(0-3)$ & $0 / 122$ & $<.0001$ \\
\hline Thromboembolic complication & $21(0-56)^{\mathrm{a}}$ & $10 / 79$ & $5(2-10)$ & $17 / 220$ & .07 \\
\hline Retreatment & $4(0-20)$ & $7 / 66$ & $7(0-25)^{a}$ & $17 / 171$ & .71 \\
\hline Treatment failure & $0(0-3.9)$ & $0 / 79$ & $6(3-9)$ & $18 / 274$ & .04 \\
\hline Midterm good neurologic outcome & $100(97-100)$ & $36 / 39$ & $99(94-100)$ & $80 / 82$ & .21 \\
\hline
\end{tabular}

${ }^{a}$ Indicates $I^{2}$ value above 50\% (substantial heterogeneity).

equate occlusion rates between $65 \%$ and $85 \%$ at midterm followup. Permanent morbidity rates ranged from $2 \%-7 \%$ depending on the series, and mortality ranged from $0 \%-17 \%$. Our study differs from the systematic review performed by Armoiry et $\mathrm{al}^{17}$ in that we conducted a formal meta-analysis and were able to pool data from 15 studies including over 550 patients. By doing so, we were able to report efficacy and complication rates with narrow confidence intervals and provide important subgroup analyses of outcomes by rupture status.

Midterm occlusion rates with the WEB device were slightly higher than those reported for stent-assisted coil treatment of wide-neck bifurcation intracranial aneurysms. Typical long-term complete or near-complete occlusion rates for coiling of wideneck and bifurcation aneurysms is generally on the order of $70 \% .{ }^{18-20}$ One recently published meta-analysis of over 2000 patients undergoing stent-assisted coiling of wide-neck bifurcation aneurysms found long-term occlusion rates of $73 \% .^{21}$ Meanwhile, our study found a long-term adequate occlusion rate of $80 \%$. Initial occlusion rates were approximately $60 \%$ with the
WEB device, compared with $54 \%$ for stent-assisted coiling of wide-neck bifurcation aneurysms. In addition to improved occlusion rates, a distinct advantage of treatment with the WEB device compared with stent-assisted coiling is the fact that pre- and/or intraoperative antiplatelet therapy is generally not required for WEB treatment. This is particularly important in the treatment of ruptured aneurysms.

Given the short length of follow-up available in many of the included studies (median of 7 months), the angiographic outcomes of the WEB device are generally similar to flow diversion. Complete occlusion rates in studies reporting 6-12 month follow-up for flow diversion typically range from $70 \%-93 \%$. $^{22-26}$ One large meta-analysis of 1451 patients with 1654 aneurysms treated with flow diverters found complete occlusion rates of $76 \%$, with a vast amount of studies reporting follow-up after less than 12 months, similar to our results. In general, occlusion rates with flow diversion improve with increased follow-up as studies with 24 months or more of follow-up report occlusion rates over $90 \%{ }^{26-28}$ Similar to flow-diversion therapy, occlusion rates with 
the WEB device generally increase with time because the healing process after placement of an intra-aneurysmal flow diverter involves a complex process of loose connective tissue deposition followed by endothelialization of the device-neck interface. Given the lack of consistent long-term (ie, $>12$ months) follow-up in the studies included in this meta-analysis, it is possible that we are in fact underestimating long-term occlusion rates.

This systematic review also demonstrated that complication rates associated with the WEB device were relatively low. Among unruptured aneurysms, perioperative morbidity rates were less than 3\% despite a thromboembolic and iatrogenic rupture rate of 9\%. Ruptured aneurysms had higher complication rates, which are likely due in part to preoperative morbidity and aneurysm complexity. Perioperative morbidity and mortality rates for stentassisted coiling of unruptured aneurysms are similar, ranging from $3 \%-5 \%$ depending on the study. ${ }^{29,30}$ One recently published meta-analysis of stent-assisted coiling of wide-neck and bifurcation aneurysms found procedure-related morbidity and mortality rates of $3 \%$ and $1 \%$, respectively. ${ }^{21}$ However, these conventional techniques are associated with poorer long-term angiographic outcomes and are hampered by the need for perioperative dual antiplatelet therapy, a factor that is particularly important in the treatment of ruptured aneurysms. ${ }^{31,32}$ Permanent morbidity and mortality rates related to flow-diverter treatment range from $8 \%-10 \% .{ }^{33}$ Thus, our findings suggest that the WEB device has a safety profile similar to flow diversion.

\section{Limitations}

The main limitation of this meta-analysis is that all the included studies were uncontrolled and many were retrospective. Many were also single-center and reported a wide variety of aneurysm morphologies and patient scenarios. There also might be variability in practice patterns and operator and medical center expertise. This is evident by the wide range of antiplatelet therapy regimens that were administered to patients before and after WEB treatment. There remains the possibility that there could be overlap in patients among studies. Although we were careful to exclude studies that had overlapping patient populations by examining the time periods studied and institutions where the patients were treated, in some cases, articles were not clear as to whether patients included in their studies were included in prior publications or in larger registries. The mean length of follow-up in the reviewed literature was modest. Another limitation is the lack of stratification of outcomes based on important variables such as type and size of the WEB device in many of the included studies. Publication bias is quite likely, and the role of the device manufacturer in the research is not fully clear. Lastly, we do not have data on baseline patient morbidity. Thus, we are unable to determine what proportion of patients with poor neurologic function at follow-up developed this after the procedure. Therefore, the overall certainty in the evidence at present is rated very low. ${ }^{34}$

\section{CONCLUSIONS}

Our meta-analysis of 15 studies including over 500 patients with over 500 aneurysms treated with the WEB device demonstrated that the WEB device has a safety profile similar to other endovascular devices such as coils and flow diverters. Furthermore, the WEB device is associated with satisfactory midterm angiographic adequate occlusion rates. These findings are particularly important given the complexity of aneurysms treated. Further prospective clinical trials, including clinical trials comparing WEB device treatment with conventional endovascular and surgical techniques, are needed to confirm these results and better define the risks and benefits of using the WEB device in treatment of wideneck and wide-neck bifurcation aneurysms.

Disclosures: Laurent Pierot-RELATED: Consulting Fee or Honorarium: Sequent; UNRELATED: Consultancy: Blockade, Medtronic, Microvention, Neural, Penumbra. David F. Kallmes—UNRELATED: Board Membership: GE Healthcare,* Comments: cost-effectiveness board; Consultancy: Medtronic, ${ }^{*}$ Comments: clinical trials planning and implementation; Grants/Grants Pending: Sequent Medical,* MicroVention, ${ }^{*}$ Codman, ${ }^{*}$ Medtronic, ${ }^{*}$ NeuroSigma, ${ }^{*}$ Surmodics, ${ }^{*}$ Comments: preclinical research and clinical trials support; Travel/Accommodations/Meeting Expenses Unrelated to Activities Listed: Medtronic, ${ }^{*}$ Comments: presentation at FDA panel meeting. *Money paid to the institution.

\section{REFERENCES}

1. Moret J, Cognard C, Weill A, et al. The "remodelling technique" in the treatment of wide neck intracranial aneurysms: angiographic results and clinical follow-up in 56 cases. Interv Neuroradiol 1997;3: 21-35 Medline

2. Nakahara $\mathrm{T}$, Hidaka $\mathrm{T}$, Kutsuna $\mathrm{M}$, et al. Intraaneurysmal embolization for wide-necked aneurysms: remodeling technique, combined neck-clipping and coiling therapy, scaffolding technique. Interv Neuroradiol 2000;6(suppl 1):95-101 Medline

3. Biondi A, Janardhan V, Katz JM, et al. Neuroform stent-assisted coil embolization of wide-neck intracranial aneurysms: strategies in stent deployment and midterm follow-up. Neurosurgery 2007;61: 460-68; discussion 468-69 CrossRef Medline

4. Mu SQ, Yang XJ, Li YX, et al. Endovascular treatment of widenecked intracranial aneurysms using of "remodeling technique" with the HyperForm balloon. Chin Med J (Engl) 2008;121:725-29 Medline

5. Lee JY, Seo JH, Cho YD, et al. Endovascular treatment of wideneck intracranial aneurysms using a microcatheter protective technique: results and outcomes in $\mathbf{7 5}$ aneurysms. AJNR Am J Neuroradiol 2011;32:917-22 CrossRef Medline

6. Pierot L, Cognard C, Spelle L, et al. Safety and efficacy of balloon remodeling technique during endovascular treatment of intracranial aneurysms: critical review of the literature. AJNR Am J Neuroradiol 2012;33:12-15 CrossRef Medline

7. Pierot L, Wakhloo AK. Endovascular treatment of intracranial aneurysms: current status. Stroke 2013;44:2046-54 CrossRef Medline

8. Ding YH, Lewis DA, Kadirvel R, et al. The Woven EndoBridge: a new aneurysm occlusion device. AJNR Am J Neuroradiol 2011;32:607-11 CrossRef Medline

9. Pierot L, Liebig T, Sychra V, et al. Intrasaccular flow-disruption treatment of intracranial aneurysms: preliminary results of a multicenter clinical study. AJNR Am J Neuroradiol 2012;33:1232-38 CrossRef Medline

10. Lubicz B, Klisch J, Gauvrit JY, et al. WEB-DL endovascular treatment of wide-neck bifurcation aneurysms: short- and midterm results in a European study. AJNR Am J Neuroradiol 2014;35:432-38 CrossRef Medline

11. Papagiannaki C, Spelle L, Januel AC, et al. WEB intrasaccular flow disruptor-prospective, multicenter experience in 83 patients with 85 aneurysms. AJNR Am J Neuroradiol 2014;35:2106-11 CrossRef Medline

12. Liebig T, Kabbasch C, Strasilla C, et al. Intrasaccular flow disruption in acutely ruptured aneurysms: a multicenter retrospective review of the use of the WEB. AJNR Am J Neuroradiol 2015;36:1721-27 CrossRef Medline 
13. Pierot L, Moret J, Turjman F, et al. WEB treatment of intracranial aneurysms: clinical and anatomic results in the French observatory. AJNR Am J Neuroradiol 2016;37:655-69 CrossRef Medline

14. DerSimonian R, Laird N. Meta-analysis in clinical trials. Control Clin Trials 1986;7:177-88 CrossRef Medline

15. Barendregt JJ, Doi SA, Lee YY, et al. Meta-analysis of prevalence. J Epidemiol Community Health 2013;67:974-78 CrossRef Medline

16. Higgins JP, Thompson SG, Deeks JJ, et al. Measuring inconsistency in meta-analyses. BMJ 2003;327:557-60 CrossRef Medline

17. Armoiry X, Turjman F, Hartmann DJ, et al. Endovascular treatment of intracranial aneurysms with the WEB device: a systematic review of clinical outcomes. AJNR Am J Neuroradiol 2016;37:868-72 CrossRef Medline

18. Pierot L, Spelle L, Vitry F. Immediate anatomic results after the endovascular treatment of unruptured intracranial aneurysms: analysis of the ATENA series. AJNR Am J Neuroradiol 2010;31:140-44 CrossRef Medline

19. Pierot L, Cognard C, Ricolfi F, et al. Immediate anatomic results after the endovascular treatment of ruptured intracranial aneurysms: analysis in the CLARITY series. AJNR Am J Neuroradiol 2010;31:907-11 CrossRef Medline

20. Brinjikji W, Murad MH, Lanzino G, et al. Endovascular treatment of intracranial aneurysms with flow diverters: a meta-analysis. Stroke 2013;44:442-47 CrossRef Medline

21. Zhao B, Yin R, Lanzino G, et al. Endovascular coiling of wide-neck and wide-neck bifurcation aneurysms: a systematic review and meta-analysis. AJNR Am J Neuroradiol 2016 Jun 2. [Epub ahead of print] CrossRef Medline

22. Puffer RC, Piano M, Lanzino G, et al. Treatment of cavernous sinus aneurysms with flow diversion: results in $\mathbf{4 4}$ patients. AJNR Am J Neuroradiol 2014;35:948-51 CrossRef Medline

23. Moon K, Albuquerque FC, Ducruet AF, et al. Resolution of cranial neuropathies following treatment of intracranial aneurysms with the Pipeline embolization device. J Neurosurg 2014;121:1085-92 CrossRef Medline

24. Szikora I, Berentei Z, Kulcsar Z, et al. Treatment of intracranial aneurysms by functional reconstruction of the parent artery: the Budapest experience with the Pipeline embolization device. AJNR Am J Neuroradiol 2010;31:1139-47 CrossRef Medline

25. Lylyk P, Miranda C, Ceratto R, et al. Curative endovascular reconstruction of cerebral aneurysms with the Pipeline embolization device: the Buenos Aires experience. Neurosurgery 2009;64:632-42; discussion 642-43; quiz N6 CrossRef Medline

26. Nelson PK, Lylyk P, Szikora I, et al. The Pipeline embolization device for the intracranial treatment of aneurysms trial. AJNR Am J Neuroradiol 2011;32:34-40 CrossRef Medline

27. Briganti F, Napoli M, Leone G, et al. Treatment of intracranial aneurysms by flow diverter devices: long-term results from a single center. Eur J Radiol 2014;83:1683-90 CrossRef Medline

28. Saatci I, Yavuz K, Ozer C, et al. Treatment of intracranial aneurysms using the Pipeline flow-diverter embolization device: a single-center experience with long-term follow-up results. AJNR Am J Neuroradiol 2012;33:1436-46 CrossRef Medline

29. Ryu CW, Park S, Shin HS, et al. Complications in stent-assisted endovascular therapy of ruptured intracranial aneurysms and relevance to antiplatelet administration: a systematic review. AJNR Am J Neuroradiol 2015;36:1682-88 CrossRef Medline

30. Hong Y, Wang YJ, Deng Z, et al. Stent-assisted coiling versus coiling in treatment of intracranial aneurysm: a systematic review and meta-analysis. PLoS One 2014;9:e82311 CrossRef Medline

31. Pierot L, Spelle L, Vitry F. Immediate clinical outcome of patients harboring unruptured intracranial aneurysms treated by endovascular approach: results of the ATENA study. Stroke 2008;39:2497504 CrossRef Medline

32. Cognard C, Pierot L, Anxionnat R, et al. Results of embolization used as the first treatment choice in a consecutive nonselected population of ruptured aneurysms: clinical results of the Clarity GDC study. Neurosurgery 2011;69:837-41; discussion 842 CrossRef Medline

33. Kallmes DF, Hanel R, Lopes D, et al. International retrospective study of the Pipeline embolization device: a multicenter aneurysm treatment study. AJNR Am J Neuroradiol 2015;36:108-15 CrossRef Medline

34. Murad MH, Montori VM, Ioannidis JP, et al. How to read a systematic review and meta-analysis and apply the results to patient care: users' guides to the medical literature. JAMA 2014;312:171-79 CrossRef Medline

35. Behme D, Berlis A, Weber W. Woven EndoBridge intrasaccular flow disrupter for the treatment of ruptured and unruptured wide-neck cerebral aneurysms: report of 55 cases. AJNR Am J Neuroradiol 2015; 36:1501-06 CrossRef Medline

36. Bozzetto Ambrosi P, Gory B, Sivan-Hoffmann R, et al. Endovascular treatment of bifurcation intracranial aneurysms with the WEB SL/ SLS: 6-month clinical and angiographic results. Interv Neuroradiol 2015;21:462-69 CrossRef Medline

37. Caroff J, Mihalea C, Dargento F, et al. Woven Endobridge (WEB) device for endovascular treatment of ruptured intracranial wideneck aneurysms: a single-center experience. Neuroradiology 2014; 56:755-61 CrossRef Medline

38. Caroff J, Mihalea C, Klisch J, et al. Single-Layer WEBs: intrasaccular flow disrupters for aneurysm treatment-feasibility results from a European study. AJNR Am J Neuroradiol 2015;36:1942-46 CrossRef Medline

39. Cognard C, Januel AC. Remnants and recurrences after the use of the WEB intrasaccular device in large-neck bifurcation aneurysms. Neurosurgery 2015;76:522-30; discussion 530 CrossRef Medline

40. Gherasim DN, Gory B, Sivan-Hoffmann R, et al. Endovascular treatment of wide-neck anterior communicating artery aneurysms using WEB-DL and WEB-SL: short-term results in a multicenter study. AJNR Am J Neuroradiol 2015;36:1150-54 CrossRef Medline

41. Lubicz B, Mine B, Collignon L, et al. WEB device for endovascular treatment of wide-neck bifurcation aneurysms. AJNR Am J Neuroradiol 2013;34:1209-14 CrossRef Medline

42. Pierot L, Klisch J, Cognard C, et al. Endovascular WEB flow disruption in middle cerebral artery aneurysms: preliminary feasibility, clinical, and anatomical results in a multicenter study. Neurosurgery 2013;73:27-34; discussion 34-35 CrossRef Medline

43. Pierot L, Spelle L, Molyneux A, et al. Clinical and anatomical follow-up in patients with aneurysms treated with the WEB device: 1-year follow-up report in the cumulated population of 2 prospective, multicenter series (WEBCAST and French Observatory). Neurosurgery 2016;78:133-41 CrossRef Medline

44. Pierot L, Costalat V, Moret J, et al. Safety and efficacy of aneurysm treatment with WEB: results of the WEBCAST study. J Neurosurg 2016;1250-56 CrossRef Medline

45. Lescher S, du Mesnil de Rochemont R, Berkefeld J. Woven Endobridge (WEB) device for endovascular treatment of complex unruptured aneurysms: a single center experience. Neuroradiology 2016;58:383-90 CrossRef Medline 